УДК 378.1

Ю. О. Бриль, викладач

(Національний технічний університет України "Київський політехнічний інститут імені Ігоря Сікорського") Julia Bril@ukr. net ORCID: 0000-00002-1094-2507

\title{
ПРАКТИКА ФОРМУВАННЯ ТА РЕАЛІЗАЦІЇ ЗМІСТОВОГО КОМПОНЕНТУ ДОКУМЕНТОЗНАВЧОЇ ОСВІТИ В УКРАЇНІ
}

\begin{abstract}
У статті критично описано та проаналізовано практику формування і реалізації змістового компоненту документознавчої освіти провідними закладами вищої освіти та культури України. Здійснено трунтовний аналіз освітніх програм і навчальних планів підготовки фахівців зі спеціальності "Документознавство та інформаційна діяльність". Узагальнено та систематизовано досвід підготовки фахівиів документно-інформаційної сфери з урахуванням потреб суспільства, ринку праці та держави у кваліфікованих фахівиях, а також з метою виявлення кращчих практик і доцільності їх використання у новій модель вищої освіти.
\end{abstract}

Ключові слова: документознавство та інформаційна діяльність, навчальна дисципліна, навчальний план, освітня програма, професійна підготовка, професійні компетениії, фахівиі.

Постановка проблеми у загальному вигляді та ії зв'язок із важливими науковими i практичними завданнями. Поступове впровадження в Україні нової освітньої парадигми безпосередньо пов'язане зі створенням і функціонуванням загальноєвропейського простору вищої освіти та досліджень, розробкою єдиних критеріїв і стандартів у сфері освіти. Зокрема, цей процес передбачає оновлення підходів до наповнення змістового компоненту підготовки фахівців документноінформаційної сфери на основі застосування технологій особистісно-орієнтованого освітнього процесу, який ставить за мету відповідати потребам сьогодення й перспективам майбутнього. Проте, на нашу думку, актуалізація змісту документознавчої освіти ускладнена без осмислення попереднього історичного досвіду, прогресивних ідей педагогів і вчених, що надасть можливість не тільки зрозуміти діалектичну сутність процесів, а й визначати перспективні напрями ії розвитку та забезпечувати потребу суспільства, ринку праці та держави у кваліфікованих фахівцях.

Актуальність дослідження визначається доцільністю ретроспективного розгляду формування та реалізації змістовного наповнення освітніх програм і навчальних планів підготовки фахівців із документознавства та інформаційної діяльності потужними науково-педагогічними колективами та лідерами наукових шкіл 3 документознавства закладів вищої освіти та культури України 3 метою виявлення кращих практик і доцільності їх використання у новій модель вищої освіти.

Аналіз основних досліджень і публікацій із зазначеної проблеми. Дослідженню стану теорії та практики розвитку документознавчої освіти в Україні присвячені праці провідних науковців: В. В. Бездрабко, Г. В. Власова, Н. А. Гайсинюк, Л. І. Демчина, С. В. Дубова, І. О. Коханова, С. Г. Кулешова, Н. М. Кушнаренко, О. В. Матвієнко, . І. Морозюк, Н. С. Назаренко, Ю. І. Палеха, Г. В. Папакіна, М. С. Слободяник, Л. Я. Філіпова, Г. М. Швецова-Водка. Проте проблематика формування і реалізації змістового компоненту підготовки документознавців ще недостатньою мірою стала предметом наукового узагальнення із залученням фундаментальних положень сучасної педагогіки.

Окреслення невирішених питань, порушених у статті. У даному дослідженні постає потреба в узагальненні та систематизації накопиченого досвіду розробки освітніх програм підготовки та навчальних планів, впровадження і реалізації підготовки фахівців за спеціальністю "Документознавство та інформаційна діяльність" в освітній системі України 3 метою забезпечення ринку праці висококваліфікованими фахівцями документно-інформаційної сфери.

Формулювання мети і завдань статті. У нашому дослідженні за мету поставлено в ретроспективі критично описати та проаналізувати практику формування та реалізації змістового компоненту документознавчої освіти вищими навчальними закладами України, що відповідали галузевому профілю "Культура". Завданнями статті є грунтовний аналіз освітніх програм і навчальних планів підготовки фахівців зі спеціальності "Документознавство та інформаційна діяльність" тих навчальних закладів, які були осередками розвитку документознавчої освіти в Україні: Київський національний університет культури і мистецтв, КНУКіМ (до 1999 р. - Київський державний університет культури і мистецтв, КДУКіМ), Харківська державна академія культури, ХДАК (до 1998 р. - Харківський державний інститут культури, ХДІК) і Національна академія керівних кадрів культури і мистецтв, НАКККіМ (до 2010 р. Державна академія керівних кадрів культури і мистецтв, ДАКККіМ).

Виклад основного матеріалу з обгрунтуванням отриманих наукових результатів. 31995 / 1996 навчального року в Україні започаткована підготовка фахівців у закладах вищої освіти та культури за 
новою спеціальністю "Документознавство та інформаційна діяльність". Труднощами становлення та розвитку документознавчої освіти стало різноманіття існуючих підходів до змісту підготовки фахівцівдокументознавців. Різноманіття підходів до змістового компоненту документознавчої освіти пояснювалося відсутністю в українській науці єдиної концепції документознавства. Зокрема, в Харківському державному інституті культури (з 1998 р. - Харківська державна академія культури) застосовувався інформаційний підхід до формування змістового компоненту підготовки, який був спрямований на розвиток інформаційної складової спорідненої спеціальності "Бібліотекознавство і бібліографія". А у Державній академії керівних кадрів культури і мистецтв (з 2010 р. - Національна академія керівних кадрів культури і мистецтв) одночасно існувало два підходи до спеціальності "Документознавство та інформаційна діяльність". Перший підхід базувався на "класичній" концепції документознавства автором, якої був професор Кулешов С. Г., інший підхід - на інформаційній концепції документознавства професора Слободяника М. С. [1: 56; 2: 4].

Основоположними нормативними документами, що відображали зміст освіти новоствореної спеціальності "Документознавство та інформаційна діяльність", стали навчальні плани освітньокваліфікаційного рівня "бакалавр", які містили дві групи навчальних дисциплін - фундаментальних і професійно-орієнтованих. До першої групи входити такі навчальні дисципліни, як: "Аналітикосинтетична переробка документної інформації", "Архівознавство", "Державне управління", "Ділові комунікації (етика та етикет)", "Документознавство", "Експертні оцінки достовірності інформації", "Захист інформації та інформаційного продукту", "Інформаційно-аналітична діяльність", "Комп'ютерні технології у документознавстві", "Лінгвістичні основи документознавства", "Основи маркетингу й менеджменту", "Основи організації праці документознавця", "Правознавство", "Редагування в документознавстві", "Справочинство", "Стандартизація та сертифікація", "Стилістика документознавства", "Теорія і практика документних комунікацій" та ін. До групи професійноорієнтованих дисциплін належали такі навчальні дисципліни, як: "Господарське право", "Маркетинг (політичний)", "Менеджмент зовнішньоекономічної діяльності", "Нотаріат, нотаріальне документознавство", "Трудові ресурси і регіоналістика". Окрім того, блок професійно-орієнтованих дисциплін навчального плану містив варіативні навчальні дисципліни за вибором як вищого навчального закладу, так і студента [1: 56-57].

Фундаментальний та професійно-орієнтований цикли навчального плану освітньо-кваліфікаційного рівня "спеціаліст" містили у собі навчальні дисципліни з документно-інформаційного забезпечення управління, інформаційного менеджменту, макроекономіки, організації представницьких заходів, психології управління, спеціального документознавства, теорії і практики управління, управління персоналом [1: 56-57].

Критично проаналізувала та оцінила тогочасні навчальні плани підготовки документознаців вітчизняна дослідниця В. В. Бездрабко, яка зауважила на слабкі міжпредметні логічні зв'язки фундаментальних і професійно-орієнтованих циклів навчальних дисциплін та дещо невдалий за змістовим наповненням перелік навчальних дисциплін професійно-орієнтованого блоку навчального плану освітньо-кваліфікаційного рівня "бакалавр". До того ж, на іiі думку, навчальні плани освітньокваліфікаційного рівня "спеціаліст" потребували суттєвого доопрацювання та доповнення, оскільки вони неповною мірою відображали інформаційний та документознавчий компонент підготовки фахівців [1: 56-57].

У 2001-2002 роках навчальні плани підготовки фахівців зі спеціальності "Документознавство та інформаційна діяльність" частково переглядалися та удосконалювалися вищими навчальними закладами, проте суттєво якісного оновлення змісту професійної підготовки не відбувалося [1: 57-58].

Одним із ключових моментів у розвитку документознавчої освіти в Україні було запровадження у 2003 році освітніх програм підготовки фахівців освітньо-кваліфікаційного рівня "магістр", навчальні плани яких також були недосконалими. Змістове наповнення навчальних планів передбачало формування у магістрів знань і вмінь щодо здійснення науково-дослідної та науково-педагогічної діяльностей. Таким чином, навчальний план складався 3 низки навчальних дисциплін, таких як: "Державна інформаційна політика", "Документно-інформаційне забезпечення управління", "Маркетинг", "Менеджмент кадрової служби", "Методологія документознавства", "Організація представницьких заходів", "Статистичні методи аналізу державної політики", "Управлінське документування", "Юридичне документоведення" та ін. Проведений В. В. Бездрабко емпіричний аналіз змісту магістерських навчальних планів показав недоцільність включення окремих навчальних дисциплін до навчального плану підготовки фахівців-документознавців, оскільки дослідниця вважає, що вони не впливають на рівень магістерської підготовки [1: 58].

Відома дослідниця Н. М. Кушнаренко зазначала, що існуючі труднощі у визначенні переліку навчальних дисциплін i його змістового наповнення та у дотриманні структурно-логічних схем викладання пов'язані, перш за все, $з$ таким: 1) відносно молода спеціальність; 2) недостатній стан 
розробленості проблематики наукою; 3) відсутність єдиних концептуальних засад методики викладання навчальних дисциплін документознавчого циклу [3: 107-108].

У межах спеціальності "Документознавство та інформаційна діяльність" напряму підготовки "Культура", відповідно до рекомендацій Міністерства культури і мистецтв України (з 2010 р. Міністерство культури України), підготовка фахівців-документознавців здійснювалася за чотирма спеціалізаціями та кваліфікаціями: 1) документно-інформаційне забезпечення архівів, кваліфікація документознавець-архівіст; 2) документно-інформаційні системи, кваліфікація - документознавець, менеджер інформаційних систем; 3) інформаційні системи підтримки державних органів управління, кваліфікація - документознавець, менеджер інформаційних систем управління; 4) міжнародні інформаційні системи і мережі, кваліфікація - документознавець, менеджер міжнародних інформаційних систем [4: 5; 5: 18$]$.

Аналізуючи період запровадження вищими навчальними закладами переліку спеціалізацій підготовки майбутніх документознавців I. І. Морозюк [5] зазначає, що постає низка проблем, які потребують вирішення - негайно, проте зазначене стосується 2003 року. Зокрема, на той період мова йшла про розбіжність змістового наповнення навчальних планів підготовки фахівців за спеціалізаціями. На нашу думку, погляд I. I. Морозюк $є$ актуальним й на сьогодні. Вирішення цих розбіжностей дослідниця вбачала у проведенні грунтовного наукового аналізу процесів, що відбувалися в освітньому середовищі професійної підготовки фахівців документознавчого профілю, та моделюванні змістового компоненту спеціальності з різноманітними спеціалізаціями, а також зосередженні уваги професійної наукової спільноти на не менш важливих речах - розробленні та обговоренні Державного галузевого стандарту вищої освіти України з документознавства та інформаційної діяльності [5: 20]. Не применшуючи внесок I. І. Морозюк у розвиток документознавчої освіти України на той період, вища документознавча освіта зазнала значних позитивних зрушень.

На вищезазначених положеннях Міністерство освіти і науки України у 2003-2004 роках, 3 метою уніфікації різноманіття існуючих підходів до процесу підготовки фахівців і змістового компоненту навчальних планів спеціальності "Документознавство та інформаційна діяльність" у вищих навчальних закладах України, створило робочу групу Державного освітнього стандарту в складі відомих вітчизняних науковців і педагогів, таких як М. С. Слободяника, С. Г. Кулешова, Н. М. Кушнаренко, Т. В. Нікітіної та ін [1: 58]. Результатом їх плідної роботи стало прийняття у 2004 році Стандарту освітньокваліфікаційного рівня освіти "бакалавр", в основу якого була покладена інформаційна концепція підготовки фахівців із документознавства та інформаційної діяльності. У Стандарті закріплено п'ять базисних змістовних блоків навчальних дисциплін: 1) загальнонауковий блок; 2) документознавчоархівний блок; 3) інформаційно-аналітичний блок; 4) комп'ютерно-технологічний блок; 5) управлінський блок [2: 4]. Ці блоки навчальних дисциплін складали навчальний план підготовки фахівців за спеціальністю "Документознавство та інформаційна діяльність" всіх вищих навчальних закладів України, водночас кожен заклад освіти мав можливість вводити до навчального плану власну варіативну компоненту за вибором вищого навчального закладу та студента, залишаючи без змін нормативну компоненту згідно стандарту.

На підставі власних попередніх досліджень [6], розглядаючи наповнення вищезазначених змістових блоків, ми розкрили п'ять циклів навчальних дисциплін, які студенти опановують у процесі освітньої підготовки:

1) документознавчий циикл: архівознавство, вступ до фаху, діловодство, документальна україніка, документознавство, документаційне забезпечення діяльності установ за фаховим спрямуванням, документознавча професіологія, методологія документознавчих досліджень, патентознавство, стандартизація та уніфікація у документознавстві та архівознавстві, управлінське документознавство та ін.;

2) інформаційний цฺикл: аналітико-синтетична переробка інформації, електронний документообіг, Інтернет-технології і ресурси, інформатика та комп'ютерна техніка, інформаційний маркетинг, інформаційний менеджмент, інформаційний моніторинг, інформаційні ресурси, інформаційні системи і технології, інформаційно-аналітична діяльність, захист інформації, консалтинг, маркетинг інформаційних продуктів і послуг, організація діяльності інформаційних установ, системи управління базами даних, системний аналіз інформаційних процесів та ін.;

3) лінгвістично-комунікаційний цүикл: документно-інформаційні комунікації, етика та психологія ділового спілкування, іноземні мови, комунікаційні технології, лінгвістичні основи документознавства, теорія і практика референтської діяльності, теорія комунікації, стилістика та редагування, українська мова за професійним спрямуванням та ін.;

4) управлінський цикл: державне управління, державотворчі процеси в Україні, документаційне забезпечення управління, історія державних установ, керування документаційними процесами, організація державного апарату, психологія управління інформаційною установою та ін.; 
5) правознавчий цикл: адміністративне право, господарське право, інтелектуальна власність, інформаційне право, цивільне право, трудове право та ін.

Таким чином, Державний галузевий стандарт вищої освіти підготовки бакалавра зі спеціальності "Документознавство та інформаційна діяльність", в якому перелік навчальних дисциплін повною мірою відповідав назві спеціальності, став одним із основних інструментів удосконалення і модернізації навчальних планів підготовки фахівців із документознавства та інформаційної діяльності низкою вищих навчальних закладів України.

Визначальним кроком у розвитку вищої документознавчої освіти стало долучення України 19 травня 2005 року до процесу інтеграції національної системи вищої освіти в загальноєвропейський освітній простір, з підтримкою принципів та цілей, які визначені у Болонській декларації "Свропейський простір у сфері вищої освіти". На думку дослідниці В. В. Бездрабко [1: 60], реалізація положень Болонського процесу та кредитно-модульної системи організації освітнього процесу сприяло: по-перше, зміцненню змістового компоненту навчальних планів, зокрема циклу професійно-орієнтованих навчальних дисциплін; по-друге, удосконаленню практики підготовки фахівців зі спеціальність "Документознавство та інформаційна діяльність", враховуючи попередній досвід; по-третє, внесенню у Національний класифікатор України ДК 003-2005 "Класифікатор професій" (на сьогодні - ДК 003:2010) низку професій - документознавець (код КП - 2432.1, код ЗКППТР - 21792), архівіст (код КП - 2431.2, код ЗКППТР 20193), менеджер у сфері надання інформації (код КП - 1473), адміністративний помічник (код КП 3423), аналітик консолідованої інформації (код КП - 2433.2), референт (код КП - 3436.1), помічник керівника (код КП - 3436.1), діловод (код КП - 4144, код ЗКППТР - 21299), організатори діловодства (код КП - 3435.1, 3435.2, 3435.3), секретар адміністративний (код КП - 3431, код ЗКППТР - 24661) та ін. [7]. Отже, внесення нових професій до ДК 003-2010 "Класифікатор професій" стало визнанням на державному рівні того, що такі професії є затребуваними на ринку праці.

Науково-педагогічний колектив Київського національного університету культури і мистецтв приділив значну увагу удосконаленню та змістовому насиченню циклу варіативних навчальних дисциплін навчальних планів освітньо-кваліфікаційного рівня "бакалавр", "спеціаліст" і "магістр", орієнтуючись на підготовку документознавців для сфери управління. Управлінський блок навчальних дисциплін містив у собі такі дисципліни, як: "Державне управління", "Організація державного апарату", "Психологія управління", "Теорія і практика управління". У зв'язку з розширенням цього блоку до навчальних планів підготовки введено навчальні дисципліни, такі як: "Антикризове управління", "Глобалістика", "Дипломатичний протокол", "Документаційне забезпечення управління", "Історія державних установ", "ПР в органах державної влади", "Прийняття управлінських рішень", "Політична праксеологія", "Соціологія управління". Водночас, педагоги здійснили доповнення документозначого циклу важливими навчальними дисциплінами, зокрема, "Керування документаційними процесами", "Наукова експертиза документів", "Законодавчо-нормативні й науково-методичні основи архівування документів установ", 3 метою вдосконалення структурно-логічної схеми та посилення міждисциплінарних зв'язків у навчальних планах професійної підготовки фахівців зі спеціальності "Документознавство та інформаційна діяльність". Удосконаленню та модернізації освітньо-професійної підготовки фахівців-документознавців, у тому числі актуалізації змістового компоненту освіти, розробленню навчально-методичних комплексів і матеріалів навчальних дисциплін, підготовці та виданню навчальних посібників і підручників сприяла активна участь науково-педагогічних працівників КНУКіМ у науково-дослідній роботі [1: 60].

Зміст підготовки фахівців 3 документознавства та інформаційної діяльності в Харківській державній академії культури, наповнення якого було орієнтоване на задоволення потреб інформаційного суспільства та забезпечення будь-якої сфери його функціонування, особливо - управлінської. Однією із основних відмінностей даного профільного вищого навчального закладу, на думку дослідниці Л. Я. Філіпової [8: 85], була насиченість змісту та форм складових навчальних дисциплін документнокультурологічного спрямування, які містили елементи з комп'ютерних та Інтернет-технологій, які на той час були сучасним інструментарієм документальних комунікацій, що потребував ринок праці, зазначене сприяло адаптації випускників ХДАК до достойного працевлаштування за фахом у будь-якій сфері соціальної діяльності, де необхідними вимогами до фахівців-документознавців було професійне опрацювання інформації та документів засобами сучасних інформаційних технологій. Л. Я. Філіпова говорить про комплексну гуманітарно-комп'ютерну підготовку студентів, яка надавала можливість випускникам після опанування фаху працювати в кадрових і архівних підрозділах різних організацій та установ, інформаційно-аналітичних службах управлінських структур та органів державної влади, інформаційних центрах науково-освітньої сфери, інформаційно-рекламних та інформаційно-патентних структурах, інших інформаційно-документних підрозділах організацій. Водночас, розвитком спеціальності "Документознавство та інформаційна діяльність" та підготовкою фахівців для східного та південного регіонів України займався науково-педагогічний колектив ХДАК у складі: Н. М. Кушнаренко (лідер харківської наукової документологічної школи), Г. Г. Асєєв, І. Г. Бондалєтов, Т. Д. Булах, 
М. П. Васильченко, І. О. Коханова, А. А. Соляник, Г. П. Терентьєва, Л. Я. Філіпова, О. П. Щербініна та iH.

Особливостями харківської наукової документологічної школи, базис формування якої був закладений ще в 60 - поч. 70-х рp. ХХ ст. і основувався на опануванні напряму документноінформаційної сфери як підготовку фахівців для органів науково-технічної інформації, було дотримання низки положень таких, як: 1) навчальний процес своєю формою та змістом базується на гуманітарній основі, зважаючи на той факт, що розвиток сучасних комп’ютерних і телекомунікаційних технологій оріснтований на високопрофесійного користувача, але не потребує грунтовної інженерної освіти; 2) актуалізація навчання зумовлена відповідністю навчальних програм сучасним вимогам професійної інформаційно-документної сфери, ринку праці й інформаційної науки; 3) навчальний процес поєднує теоретичні та практичні елементи; 4) навчання спрямоване на адаптивність, тобто спектр навчальних дисциплін має забезпечити можливості професійної та соціальної адаптації випускників в умовах складного розвитку інформаційного ринку України; 5) конвертація навчальних програм передбачає їх сумісність зі стандартами вітчизняної та зарубіжної інформаційної освіти [9: 265].

Тогочасні основні тенденції світового розвитку інформаційно-документних наук і практики та вищезазначені положення були враховані в навчальних планах підготовки документознавців у ХДАК.

Факультет документознавства та інформаційної діяльності ХДАК тривалий час мав одну спеціальність "Документознавство та інформаційна діяльність" з кваліфікацією "документознавець, спеціаліст з інформатики" та 4 спеціалізації. Підготовка фахівців 3 документознавства та інформаційної діяльності охоплювала три напрями: 1) гуманітарна інформатика (наукова, соціальна, теоретична), документознавство (управлінське, лінгвістичне та ін.), документалістика; 2) інформаційна діяльність: інформаційно-аналітична, інформаційно-патентна, інформаційний менеджмент i маркетинг; інформаційне моделювання, експертиза та прогнозування; інформаційне право, інформаційнокомп’ютерна етика; 3) інформаційно-документне забезпечення управління, архівної та музейної справи, засобів масової інформації, інших сфер соціальної діяльності [9: 265].

Студенти Академії починали знайомитися 3 обраним фахом вивчаючи основоположні фахові навчальні дисципліни документознавчого циклу - на першому курсі "Діловодство", на другому курсі "Документознавство", на третьому курсі "Архівознавство" та "Документне забезпечення управління", на четвертому курсі "Управлінське документознавство", а також інші навчальні дисципліни, що формували систему професійних компетентностей документознавця такі, як: "Аналітико-синтетична обробка документів", "Документне фондознавство", "Документні інформаційно-пошукові системи", "Документні ресурси", "Документологія", "Електронний документообіг", "Зберігання та реставрація документів", "Інтелектуальне право", "Книгознавство", "Консервація та реставрація документів", "Патентна та ліцензійна діяльність", "Теорія і практика редагування" та ін. [9: 269-271].

Навчальний процес на факультеті був організований відповідно до чинної нормативно-правової бази освітньої сфери 3 дотриманням вимог до змісту професійних компетенцій та компетентностей 3 документознавства та інформаційної діяльності. До основних загальнопрофесійних компетенцій документознавця, дослідниця Л. Я. Філіпова відносить [8: 87]: здатність використовувати знання, уміння й навички в галузі теорії й практики управління інформацією та документообігом у будь-якій установі; здатність планувати й реалізувати відповідні заходи в інформаційно-документній сфері; знання правових основ і законодавства України в галузі інформатизації суспільства та документального забезпечення сфери управління й інших галузей; здатність до ділових комунікацій у професійній сфері, навички роботи в команді та ін., які формуються та реалізуються у процесі професійної підготовки за допомогою комплексу фахових навчальних дисциплін. При цьому, дослідницею робиться наголос на тому, що особливе значення мають збалансовані компетенції такі, як інформаційна, комунікаційна та культурна, що одночасно для фахівців-документознавців $є$ як загальними, так і професійними.

У ХДАК пріоритетним напрямом предметної галузі зі спеціальності "Документознавство та інформаційна діяльність" була інформаційно-аналітична діяльність (референтська, консультаційна), проте поряд з цим напрямом існували й інші, зокрема діловодсько-кадрова й організаційно-управлінська діяльності. Блок інформаційно-аналітичної діяльності містив у собі такі основні спеціалізованопрофесійні компетенції, як: знання й уміння у галузі теоретичних основ інформатики й практичного використання комп'ютерних технологій; навички роботи з комп'ютером на рівні користувача, уміння використовувати інформаційні технології для вирішення практичних завдань в інформаційнодокументній сфері; здатності опанувати методи та засоби інформаційної аналітики, проводити інформаційний моніторинг на базі ресурсів Інтернет за конкретними запитами, аналітико-синтетичну обробку документів та інформації, готувати відповідні аналітичні огляди та реферати; здатність використовувати уміння й навички щодо формування інформаційних ресурсів установи, зокрема 3 використання засобів комп'ютерних (апаратне та програмне забезпечення) та Інтернет-технологій (електронних продуктів і послуг) тощо. Таким чином, випускник факультету документознавства та 
інформаційної діяльності ХДАК у процесі навчання опановував системою професійних компетенцій та отримував відповідну кваліфікацію [8: 87-88].

Перспективні напрями розвитку спеціальності "Документознавство та інформаційна діяльність" у ХДАК на 2009 рік були пов'язані: по-перше, з актуалізацією науково-методичної діяльності профільного факультету та кафедр, зокрема за участю науково-педагогічного колективу в науково-дослідних робота, проектах, грантах; по-друге, з впровадженням інноваційних технологій та методик у навчальний процес; по-третє, 3 розробкою варіативних професійних магістерських програм підготовки фахівців 3 документознавства та інформаційної діяльності. Зокрема, Академією було визначено та запропоновано п'ять магістерських програм: 1. Магістерська програма (академічна) - спеціалізація: "Теорія та історія документознавства та гуманітарної інформатики", кваліфікація: "документознавець-дослідник"; 2. Магістерська програма (професійна, прикладна) - спеціалізація: "Управління документноінформаційними системами", кваліфікація: "документознавець-менеджер інформаційних систем, викладач"; 3. Магістерська програма (професійна, прикладна) - спеціалізація: "Інформаційне забезпечення архівних установ", кваліфікація: "документознавець-архівіст, викладач"; 4. Магістерська програма (професійна, прикладна) - спеціалізація: "Науково-інформаційна та патентна діяльність", кваліфікація: "документознавець-патентознавець в інформаційній діяльності, викладач"; 5. Магістерська програма (професійна, прикладна) - спеціалізація: "Інформаційно-аналітична діяльність", кваліфікація: "документознавець-інформаційний аналітик, викладач" [8: 90]. Вищезазначене було суттєвим проривом, поштовхом до подальшої уніфікації документознавчої освіти. Кожна 3 цих спеціалізацій в основному відображали ті окремі вектори розвитку документознавства як науки та навчальної дисципліни, які були притаманні тому історичному періоду та склали підгрунтя для наступного розвитку цієї сфери в інформаційно-комунікаційному середовищі, що на той період затребував ринок праці в Україні.

Іншою практикою успішного впровадження та реалізації змістового компоненту документознавчої освіти в Україні вважаємо розробки кафедри документальних комунікацій Державної академії керівних кадрів культури і мистецтв, яку очолював доктор історичних наук, професор, лідер однієї із наукових шкіл документознавства М. С. Слободяник. Під його керівництвом науково-педагогічний колектив кафедри здійснював підготовку фахівців зі спеціальності "Документознавство та інформаційна діяльність" за освітньо-кваліфікаційними рівнями "бакалавр" (термін навчання - 4 роки), "спеціаліст" (термін навчання - 1 рік) і "магістр" (термін навчання - 1,5 років на денній формі навчання, 2 роки на заочній формі навчання). В Академії підготовка документознавців провадилася за кваліфікаціями "документознавець фінансових, банківських і підприємницьких структур", "документознавець-менеджер служб управління персоналом", "документознавець-референт органів державної влади та місцевого самоврядування". Розглянемо більш детально специфіку підготовки випускників за цими кваліфікаціями.

Унікальна, на той час, кваліфікація "документознавець фінансових, банківських і підприємницьких структур" передбачала додаткову спеціальну підготовку 3 організації ефективного використання Інтернет-ресурсів у банківській справі та підприємництві, в інформаційно-аналітичному, документаційному забезпеченні діяльності банків і підприємницьких структур, з економічного аналізу, фінансів, банківської справи, бухгалтерської справи, бухгалтерського обліку i аудиту організації підприємницької діяльності. При цьому успішній професійній адаптації випускників сприяла навчальна практика у провідних банках і підприємницьких структурах.

Студенти, які навчалися за кваліфікацією "документознавець-менеджер служб управління персоналом" отримували додаткову підготовку з організації діяльності та інформаційно-аналітичного забезпечення державного апарату та інших органів управління, 3 ефективного використання інформаційних ресурсів органів влади, аналізу соціально-політичних процесів. До того ж реалізація практичного компоненту передбачала ознайомлення з роботою відділів документаційного забезпечення управління, архівів, кадрових підрозділів органів державної влади.

Випускники 3 кваліфікацією "документознавець-менеджер служб управління персоналом" одержували додаткову підготовку в сфері організації діяльності служби управління персоналом і самостійних кадрових агенцій, кадрового діловодства, трудового законодавства, ефективного управління персоналом, психології спілкування, управління потоками кадрової документації, а професійній адаптації випускників сприяло проходження практики у провідних кадрових агенціях.

Студенти-документознавці в процесі фахової підготовки отримували знання і практичні навички для висококваліфікованого інформаційного, документаційного, аналітико-прогностичного забезпечення усіх сфер життєдіяльності суспільства з використанням сучасних технологій. Така фахова підготовка надала змогу випускникам спеціальності "Документознавство та інформаційна діяльність" працювати керівниками та провідними спеціалістами підрозділів державного апарату, у підрозділах інформаційноаналітичного та документаційного забезпечення управління, інформаційного моніторингу, управління персоналом, маркетингово-аналітичної діяльності, електронного документообігу, вести власний інформаційний бізнес [2: 5]. 
До прикладу, у ДАКККіМ навчальний план підготовки бакалаврів за спеціальністю "Документознавство та інформаційна діяльності" кваліфікацією "документознавець фінансових, банківських і підприємницьких структур" 2008 року набору становив 5383 годин навчального навантаження, 48 навчальних дисциплін і передбачав проходження виробничої практики, комплексний державний іспит і захист дипломної роботи.

Документознавчий цикл містив 6 навчальних дисциплін: "Архівознавство", "Діловодні процеси", "Документознавство", "Кадрове діловодство", "Патентознавство", "Управлінське документознавство". Інформаційний цикл включав у себе 10 навчальних дисциплін таких, як: "Аналітико-синтетична переробка інформації", "Електронний документообіг", "Інформаційний менеджмент", "Інформаційні системи і технології", "Інформаційно-аналітична діяльність", "Маркетинг інформаційних продуктів і послуг", "Міжнародна інформація", "Організація діяльності інформаційних установ", "Системи управління базами даних", "Системний аналіз інформаційних процесів". Лінгвістично-комунікаційний цикл складався 35 навчальних дисциплін: "Документно-інформаційні комунікації", "Іноземна мова", "Комунікативні технології", "Лінгвістичні основи документознавства", "Організація референтської та офісної діяльності". Управлінський цикл містив у собі 6 навчальних дисциплін таких, як: "Державне управління", "Державотворчі процеси в Україні", "Електронний уряд", "Організація державного апарату", "Кадровий менеджмент", "Психологія управління інформаційною установою". До правознавчого циклу входило 2 навчальні дисципліни: "Адміністративне право" та "Трудове право". Решта, а це 10 навчальних дисциплін, є загальноосвітніми.

Фахівці, які формували навчальний план підготовки "бакалавра" за спеціалізацією "документознавець фінансових, банківських і підприємницьких структур" вирішили, що у той проміжок часу актуальними для ринку праці будуть спеціалісти 3 документознавства, які вивчали саме такі дисципліни з циклу професійно-орієнтованих, як: "Банківська справа", "Банківська та підприємницька інформація в Інтернеті", "Банківські операції", "Бухгалтерський облік і аудит", "Гроші і кредит", "Документаційне забезпечення діяльності банку", "Документаційне забезпечення підприємства", "Стратегія розвитку підприємницької структури", "Фінанси".

Навчальний план підготовки магістрів за спеціальністю "Документознавство та інформаційна діяльність" кваліфікацією "документознавець фінансових, банківських і підприємницьких структур" у НАКККіМ 2010 року становив 3024 години навчального навантаження, 28 навчальних дисциплін і передбачав проходження переддипломної практики, захист дипломної роботи.

При аналізі змістового наповнення освітньо-професійної програми підготовки магістрівдокументознавців фінансових, банківських і підприємницьких структур спостерігаємо поглиблення фундаментальної складової підготовки. Зазначене $є$ вагомим внеском у розвиток документознавчої освіти, яку здійснили компетентні розробники навчальних планів, а саме науково-педагогічний колектив Академії під керівництвом професора М. С. Слободяника. Зокрема, відбулося насичення плану документознавчими та архівознавчими навчальними дисциплінами 3 архівної евристики, документознавчої професіології, документальної україніки, документології, міжнародного архівного співробітництва, методології документознавчих досліджень, теоретичних засад документознавства та архівознавства, стандартизації та уніфікації у документознавстві та архівознавстві; інформаційними навчальними дисциплінами 3 інформаційної економіки, інформаційного моніторингу, інформології, консалтингу, управління інформаційними проектами, ПР технологій і реклами в інформаційній сфері, теорії інформаційних потоків, теорії згортання інформації. Спеціалізована компонента магістерського плану містила навчальні дисципліни 3 аналітико-прогностичного забезпечення банківської діяльності, банківського менеджменту, інформаційно-аналітичного забезпечення фінансової і банківської діяльності, керування документацією, конфліктології (за фаховим спрямуванням), менеджменту архівнодокументальних систем (за фаховим спрямуванням). Варто відзначити те, що в освітньо-професійній програмі підготовки магістрів у НАКККіМ, науково-педагогічним колективом було внесено до плану такі навчальні дисципліни, як: "Менеджмент освіти", "Основи наукових досліджень та організація науки", "Педагогіка та методика викладання у вищій школі", "Українська мова (для науки, аналітичної сфери та управління)", що свідчить про рівень магістра не тільки як професіонала, але й педагоганауковця.

Г. В. Папакін у своєму дослідженні [4: 7] здійснив критичний аналіз освітньо-професійної програми підготовки кваліфікованих кадрів із документознавства та інформаційної діяльності у НАКККіМ у 2012 році, яка передбачала опанування студентами навчальних дисциплін у кількості 90, 3 яких 17 навчальних дисциплін є документозначими: "Діловодство", "Документознавство", "Документознавча професіологія", "Електронний документообіг", "Історичне документознавство", "Кадрове діловодство", "Керування документацією", "Комп'ютерні технології в діловодстві", "Лінгвістичні основи документознавства", "Менеджмент архівно-документальних систем", "Методологія документознавчих досліджень", "Національна система електронно-цифрового підпису", "Нотаріат та нотаріальне документування", "Стандартизація документно-інформаційної сфери", "Стандартизація і сертифікація в 
документознавчій сфері", "Судово-процесуальне документознавство", "Термінологічні засади документознавства і архівознавства", "Управлінське документознавство" та 2 архівознавчі навчальні дисципліни - "Архівна евристика" та "Архівознавство". Управлінський цикл навчальних дисциплін містив 8 навчальних дисциплін: "Державна інформаційна політика", "Державне управління", "Електронне урядування", "Інновації державного управління", "Історія державних установ і організацій", "Організація державного апарату", "Теоретичні засади державного управління", "Технічні засоби управління". Інші навчальні дисципліни належать до загальноосвітнього, лінгвістико-термінологічного, інформаційного та комунікаційного циклів. Науковець Г. В. Папакін, проаналізувавши вищеописану освітньо-професійну програму підготовки фахівців із вищою документознавчою освітою, зробив висновок про надмірну кількість незначних за обсягом годин навчального навантаження окремих дисциплін та відзначив те, що спостерігається відсутність фундаментальності та комплексності у викладанні базових професійних навчальних дисциплін. У цілому, ми погоджуємося 3 висновками науковця.

Дослідження кількісних характеристик змістового компоненту навчальних планів (освітньопрофесійних програм) підготовки бакалаврів і магістрів (2008, 2010, 2012 рр.) даного вищого навчального закладу в комплексі, надало можливість стверджувати, що така підготовка документознавців передбачала поглиблення галузевої та професійної складової фахової підготовки. До того ж, лідер однієї із наукових шкіл документознавства М. С. Слободяник [2: 5] зазначав, що слід дотримуватися гармонійного поєднання фундаментальної, професійної та спеціалізованої підготовки фахівців зі спеціальності "Документознавство та інформаційна діяльність", оскільки це був і є одним із основних напрямів розвитку вищої документознавчої освіти в Україні.

Безперечно, практика формування та реалізації змістового компоненту з кожним навчальним роком сприяла становленню і розвитку документознавчої освіти в Україні. Спеціальність "Документознавство та інформаційна діяльність" поширювалася серед вітчизняних вищих навчальних закладів різного профілю (як універсальних, так і галузевих, як гуманітарних, так і технічних) і різної форми власності (державної та приватної).

Висновки та перспективи подальшого дослідження проблеми. Реалізація основних завдань щодо розвитку інформаційного суспільства та інформаційної інфраструктури в Україні зумовило започаткування підготовки кадрів за спеціальністю "Документознавство та інформаційна діяльність". 3 огляду на відсутність в Україні практики підготовки фахівців із документознавства та інформаційної діяльності родоначальниками здійснення такої підготовки стали провідні заклади вищої освіти та культури, традиційними напрямами підготовки яких були бібліотечні, книгознавчі спеціальності Київський національний університет культури і мистецтв, Харківська державна академія культури і Національна академія керівних кадрів культури і мистецтв. За сприяння науково-педагогічних колективів суміжних напрямів підготовки відбулося формування i реалізація змістового компоненту документознавчої освіти, який характеризувався різноманіттям існуючих підходів до змісту підготовки фахівців-документознавців; слабкими міжпредметними логічними зв'язками фундаментальних i професійно-орієнтованих циклів навчальних дисциплін; труднощами у визначенні переліку навчальних дисциплін і його змістового наповнення та у дотриманні структурно-логічних схем викладання тощо. Проте 3 уніфікацією спеціальності та прийняттям Державного галузевого стандарту вищої освіти відбулося якісне удосконалення змістового компоненту підготовки фахівців-документознавців за рахунок наповнення навчальних планів єдиними базисними змістовними блоками навчальних дисциплін, такими як: загальнонауковий, документознавчо-архівний, інформаційно-аналітичний, комп'ютернотехнологічний, управлінський.

Вважаємо, що подальший напрям досліджень має бути спрямований на розгляд змістового компоненту освітніх програм підготовки фахівців документно-інформаційної сфери за останні декілька років, що надало б можливість виявити наявність використання кращих практик на сьогодення.

\section{СПИСОК ВИКОРИСТАНИХ ДЖЕРЕЛ ТА ЛІТЕРАТУРИ}

1. Бездрабко В. В. Документознавча освіта в Україні : становлення, сучасний стан і перспективи / В. В. Бездрабко // "Гілея (науковий вісник)". - 2009. - Випуск 20. - С. 56-66.

2. Слободяник М. С. Становлення та розвиток вищої документознавчої освіти в Україні / М. С. Слободяник // Бібліотекознавство. Документознавство. Інформологія. - 2011. - № 3. - С. 4-5.

3. Кушнаренко Н. М. Внутріпредметна і міжпредметна інтеграція дисциплін документознавчого циклу / Н. М. Кушнаренко // Вісник Харківської державної академії культури : [збір. наук. праць]. - 2003. - Вип. 11. - С. 106-114.

4. Папакін Г. В. До проблеми змістовного наповнення навчальної підготовки документознавців у Національній академії керівних кадрів культури і мистецтв / Г. В. Папакін // Бібліотекознавство. Документознавство. Інформологія. - 2013. - № 2. - С. 4-8.

5. Морозюк I. І. Документознавство та інформаційна діяльність: проблеми спеціалізацій і вимоги практики / I. І. Морозюк // Вісник Книжкової палати. - 2003. - № 8. - С. 18-20. 
6. Бриль Ю. О. Зміст професійної підготовки фахівця зі спеціальності "Документознавство та інформаційна діяльність" в Україні / Ю. О. Бриль // Документ, мова, соціум: теорія і практика: матеріали Міжнар. наук.практ. конф., Київ, 11-12 квіт. 2013 р. / М-во культури України, М-во освіти і науки, Нац. акад. керів. кадрів культури і мистецтв, Ін-т менеджменту, Каф. документознавства та упр. соціал. комунікаціями. - К. : [НАКККіМ], 2013. - 168 с. - C. 6-7.

7. Національний класифікатор України "Класифікатор професій" ДК 003:2010 (На зміну ДК 003:2005) [Електронний ресурс]. - Чинний від 01.11.2010 p. - Режим доступу : https:/hrliga.com/docs/327_KP.htm. Назва $з$ екрану.

8. Філіпова Л. Я. Спеціальність "Документознавство та інформаційна діяльність" у Харківській державній академії культури : пріоритети навчання та перспективи розвитку / Л. Я. Філіпова // Вісник Харківської державної академії культури. - 2009. - Вип. 27. - С. 83-91.

9. Коханова І. О. Харківська наукова документологічна школа / I. О. Коханова // Вісник Харківської державної академії культури. - 2011. - Вип. 34. - С. 264-272.

\section{REFERENCES (TRANSLATED \& TRANSLITERATED)}

1. Bezdrabko V. V. Dokumentoznavcha osvita v Ukraini : stanovlennia, suchasnyi stan i perspektyvy [Records Management Education in Ukraine : Formation, Baseline Conditions and Prospects] / V. V. Bezdrabko // "Hileia (naukovyi visnyk)" [Gilea (Scientific Bulletin)]. - 2009. - Vypusk 20. - S. 56-66.

2. Slobodianyk M. S. Stanovlennia ta rozvytok vyshchoi dokumentoznavchoi osvity v Ukraini [Formation and Development of Higher Education in the Field of Records Management in Ukraine] / M. S. Slobodianyk // Bibliotekoznavstvo. Dokumentoznavstvo. Informolohiia [Library Science. Record Studies. Informology]. - 2011. № 3. - S. 4-5.

3. Kushnarenko N. M. Vnutripredmetna i mizhpredmetna intehratsiia dystsyplin dokumentoznavchoho tsyklu [Intrasubject and Interdisciplinary Integration of the Disciplines of the Records Management Course] / N. M. Kushnarenko // Visn. Khark. derzh. akad. Kul'tury [Visnyk of Kharkiv State Academy of Culture: Scientific Papers] : [zbir. nauk. prats']. - 2003. - Vyp. 11. - S. 106-114.

4. Papakin H. V. Do problemy zmistovnoho napovnennia navchalnoi pidhotovky dokumentoznavtsiv u Natsionalnii akademii kerivnykh kadriv kul'tury i mystetstv [To the Problem of the Conceptual Content of the Records Management Specialists' Training at the National Academy of Government Managerial Staff of Culture and Arts] / H. V. Papakin // Bibliotekoznavstvo. Dokumentoznavstvo. Informolohiia [Library Science. Record Studies. Informology]. - 2013. - № 2. - S. 4-8.

5. Moroziuk I. I. Dokumentoznavstvo ta informatsiina diial'nist' : problemy spetsializatsii i vymohy praktyky [Records Management and Information Activity : Problems of Majoring and Practice Requirements] / I. I. Moroziuk // Visnyk Knyzhkovoi palaty [The Journal Bulletin of the Book Chamber]. - 2003. - № 8. - S. 18-20.

6. Bryl Iu. O. Zmist profesiinoi pidhotovky fakhivtsia zi spetsialnosti "Dokumentoznavstvo ta informatsiina diialnist"" v Ukraini [Content of the Professional Qualifications of Specialists in the Field of "Records Management and Information Activity" in Ukraine] / Iu. O. Bryl // Dokument, mova, sotsium: teoriia i praktyka [Document, Language, Society: Theory and Practice] : materialy Mizhnar. nauk.-prakt. konf., Kyiv, 11-12 kvit. 2013 r. / M-vo kul'tury Ukrainy, M-vo osvity i nauky, Nats. akad. keriv. kadriv kultury i mystetstv, In-t menedzhmentu, Kaf. dokumentoznavstva ta upr. sotsial. komunikatsiiamy. - K. : [NAKKKiM], 2013. - 168 s. - S. 6-7.

7. Natsional'nyi klasyfikator Ukrainy "Klasyfikator profesii" DK 003:2010 (Na zminu DK 003:2005) [National Classifier of Occupations of Ukraine] [Elektronnyi resurs]. - Chynnyi vid 01.11.2010 r. - Rezhym dostupu : https://hrliga.com/docs/327_KP.htm. - Nazva z ekranu.

8. Filipova L. Ia. Spetsialnist' "Dokumentoznavstvo ta informatsiina diial'nist" u Kharkivskii derzhavnii akademii kul'tury : priorytety navchannia ta perspektyvy rozvytku [Qualification in "Records Management and Information Activity" at the Kharkiv State Academy of Culture: Educational Priorities and Development Prospects] / L. Ia. Filipova // Visnyk Kharkivskoi derzhavnoi akademii kultury [Visnyk of Kharkiv State Academy of Culture : Scientific Papers]. - 2009. - Vyp. 27. - S. 83-91.

9. Kokhanova I. O. Kharkivs'ka naukova dokumentolohichna shkola [Kharkiv Scientific Records Management School] / I. O. Kokhanova // Visnyk Kharkivskoi derzhavnoi akademii kultury [Visnyk of Kharkiv State Academy of Culture : Scientific Papers]. - 2011. - Vyp. 34. - S. 264-272.

\section{Бриль Ю. А. Практика формирования и реализации содержательного компонента документоведческого образования в Украине.}

В статье критически описано и проанализировано практику формирования и реализации содержательного компонента документоведческого образования ведущими заведениями высшего образования и культуры Украиньл. Осуществлен основательный анализ образовательньх программ и учебных планов подготовки специиалистов по специальности "Документоведение и информационная

деятельность". Обобщен и систематизирован опьт подготовки специалистов документоинформационной сферы с учетом потребностей общества, рынка труда и государства в квалифиџированных специалистах, а также с иелью выявления лучших практик и целесообразности их использования в новой модели высшего образования. 
Ключевые слова: документоведение и информационная деятельность, учебная дисииплин, учебный план, образовательная программа, профессиональная подготовка, профессиональные компетенции, специалистыл.

\section{Bryl Yu. O. Development and Implementation of the Conceptual Component of Records Management Education in Ukraine.}

The article describes and analyses the development and implementation of the conceptual component of records management education by the leading higher educational and cultural institutions of Ukraine, traditionally majoring in library and book science - Kiev National University of Culture and Arts, Kharkiv State Academy of

Culture and National Academy of Government Managerial Staff of Culture and Arts.

The detailed analysis of the curricula and syllabuses for the specialists training in the field of "Records Management and Information Activity" was conducted. The abovementioned curricula and syllabuses are characterized by the diversity of the existing approaches to the training content of the specialists in the field of records management; weak interdisciplinary logical connections of the fundamental and vocational-oriented courses of the academic disciplines; difficulties in determining the list of academic disciplines and their subject matter, as well as in complying with the structural and logical concept of teaching, etc. However, the conceptual component of the records management specialists' education has improved qualitatively as the result of the

specialty unification and the adoption of the State industrial standard for higher education due to the provisioning of the curricula with the unified basic content blocks of academic disciplines, such as general scientific, archives and records management, information analysis, computer and technology, as well as management.

The experience of specialists training in the field of records management and information activity is generalized and systematized considering the society, labour market and state necessity for the qualified specialists, as well as to identify the best practices and relevance of their application within the context of the new higher education model.

Key words: records management and information activity, curriculum, syllabus, educational program, vocational training, professional competence, specialists. 